\title{
THE SLAVIC IDEA AND THE ORIGIN \\ OF BULGARIAN FOLKLORE STUDIES
}

\section{VLADIMIR PENCHEV}

This paper presents various concepts of Slavic ethnic and cultural identity and their influence on the formation of knowledge about the Slavs in ethnography and folklore studies, including the impact on the Bulgarian lands. The origin and the development of Bulgarian ethnology is analyzed in this context. The findings indicate that Bulgarian ethnology focuses almost entirely on studying Bulgarian folk culture beyond the paradigms of Slavic.

Keywords: Bulgarian ethnology, folk culture, identity, Slavic idea.
Avtor prestavlja različne koncepte slovanske etnične in kulturne identitete in njihov vpliv na oblikovanje znanja o Slovanih $v$ etnografskih raziskavah; $v$ tem kontekstu analizira tudi razvoj bolgarske etnologije. Analiza kaže, da so se bolgarski raziskovalci $v 19$. stoletju skoraj izključno posvečali le bolgarski ljudski kulturi, ne da bi se zgledovali po slovanski paradigmi. Ključne beside: bolgarska etnologija, ljudska kultura, slovanska ideja, identiteta.

At the end of nineteenth century and throughout the entire twentieth century, a process of self-identification of Slavic societies took place in parallel with the development of the Slavic nations and national self-awareness. The main goal of this trend was to differentiate the Slavs from German and Romance areas, to bring to the fore their ethnic base, and to manifest a common Slavic identity. In some places, this path became the main weapon in the ideology and practice of the various national liberation movements in a wide spectrum, from extremely radical approaches to the most conservative ones. Perhaps for this very reason, even though an awareness of Slavic ethnic identity was borne in mind in all cases, the wording of the essence and mechanisms of the manifestation of Slavic identity were constructed in various concepts with a philosophical, ideological, cultural, historic, and political basis. Although there were even differences in the names themselves (the Slavic idea, Slavic reciprocity, Slavic solidarity, Slavic unity, etc.), ultimately they involved one and the same thing: a combination of forms and manifestations of social awareness, grounded in the notion of genetic kinship among the Slavic ethnic groups.

In spite of the differences in their main basis—-their goals and purposes-all of these concepts built a relatively consistent system, revealing the development of Slavic social awareness during a comparatively long period of time. Very often they merged into one another, overlapped, referred to a previous movement, and became a foundation for the next. Hence it is appropriate to unite them under a common denominator 
such as the term "Slavisms." ${ }^{1}$ Chronologically, the first Slavism to develop was the Polish messianic doctrine. The driving idea in this concept was that the Slavs (led by the Poles) were elected by God to perform the great task of reviving all of mankind and supporting the victory of genuine and perfect Christianity. Chronologically, the philosophical basis of this concept was German philosophy after Kant as developed by Schelling and Hegel. In some sense, the Polish messianic doctrine also advanced the messianic ideas of Jurij Križanić, a seventeenth-century Croatian scholar and writer of encyclopedic knowledge whose treatises promoted a program for clerical, linguistic, cultural, and even political integration of the Slavs based on the opinion that they were the better part of mankind, predetermined to carry it to the shining vaults of heaven. Similar notes sounded on Polish territory among Herder's contemporaries, such as Stanisław Staszic and Jan Pawel Woronicz, but the concept itself did not receive its final form until the 1820s, mostly due to the efforts of its ideologist Józef Maria Hoene-Wroński. As a whole, the Polish messianic doctrine encompassed several branches, including a mystical one led by Andrzej Towiański (who attracted prominent writers such as Adam Mickiewicz and Juliusz Słowacki), a philosophical branch headed by August Cieszkowski (his followers included Zygmunt Krasiński), the orthodox Catholic branch of Józef Gołuchowski, and the political branch of Bronisław Ferdynand Trentowski.

The ideas of the Polish Slavic messianic doctrine directly influenced the formation and development of Slavism, which came next in the 1830s. This concept was mainly known as the idea of Slavic reciprocity/Mutuality, or Kollárism after the name of its creator, the Slovak Revival-era writer Ján Kollár. Kollárism was also based on Križanić’s baroque Slavism (to use Wollman's expression), but it was mostly based on the philosophy of the Enlightenment and Romanticism. This fact explains the expression of patriotism among its followers, mainly manifested as a belief in the predetermination of the Slavs as an elect people. Kollárism particularly emphasized the notion of a united Slavic people, based on tribal affinity and insignificant differences in languages. For Kollár and his followers, the fact that Slavs are a meta-ethnic community, that the various Slav ethnic groups are completely differentiated, was not essential at all. In Kollár's view, there were no populations and languages, but tribes and dialects, and the criteria for their differentiation were not quite clear. With a powerful Romantic gesture, he tried to unite the entire Slavic ethnic territory by focusing on and raising awareness of the spiritual powers of the Slavs. Kollárism found an extremely cordial reception in the Slavic world and many prominent Slavic intellectuals of that time become followers. Among them, František Ladislav Čelakovský, Pavel Josef Šafárik, and Karel Jaromír Erben stand out.

1 This term was already used in the nineteenth century by the Russian philosopher Konstantin Leontyev (see Leontyev 1875; available at: http://knleontiev.narod.ru/texts/vizantizm.htm\#a), and later by the Czech Slavic specialist Frank Wollman (1928). The two of them gave a different meaning to the notion, but both of them used it to designate various concepts of Slavic ethnic identity. 
Kollár's ideas directly and immediately influenced the development of a series of new Slavisms during the 1830s, 1840s, and 1850s. Although they originated at one and the same time, they were not all-embracing, but focused their aims and purposes on particular ethnic territories. They were strongly politicized in one or another period of their existence.

First of all, one must mention Austro-Slavism, a program that was mainly formulated in the Czech lands of the Habsburg Empire. The main goal of this project was to reconstruct the state on a federal principle and to achieve a balance between its German and the Slavic elements. Austro-Slavism was founded as a reaction to developing German chauvinism. It had strong positions during the 1860s, but after the blow delivered by the Austro-Hungarian Compromise in 1867 it gradually declined, although the concept had some social influence until the First World War. In a practical sense, it was limited to the Slavic idea that was already formulated in the Habsburg Empire. The followers of this concept mainly came from Czech, Slovak, Slovenian, and Croatian intellectual circles. The credit for developing Austro-Slavism's conceptual basis goes almost entirely to Czech leaders and politicians such as Count Leopold Lev Thun, Karel Havlíček Borovský, and František Palacký.

Illyrianism, which came into being at the same time, had a similar kind of ideological content. This movement was also based on the ideas of Križanić and Kollár. Its main goal was to create Great Illyria, a state uniting the South Slavic lands. At that time, the people of this area were considered the successors of its ancient inhabitants, the Illyrians. According to Illyrianism, the Illyrians were Slavic in origin. Logically, this Slavism was most widespread in Croatian, Slovenian, and Serbian territory (but not in Bulgaria). Its main representatives were the Croatians Ljudevit Gaj and Ivan Kukuljević. The main goal of their concept was the spiritual and linguistic unity of South Slavs, which in time would lead to their political integration. For this reason the codification of a common Serbo-Croatian language was an important practical achievement.

The situation related to Russian Slavophilia was quite different. This concept took shape in the 1840s and the 1850s in the context of Russian philosophical thought, which at that time opposed another trend: Westernization. Although at first glance Slavophilia was a completely Russian phenomenon, its nature was common to all Slavic peoples because it was warmly accepted in other Slavic countries (among the Czechs, Slovaks, Poles, Serbs, and Bulgarians) and because it advanced universal Slavic ideas. Its most prominent founders include Ivan Kireyevsky, Aleksey Khomyakov, Konstantin Aksakov, and Yuri Samarin. The movement was supported by Vladimir Dal, Aleksandr Ostrovsky, Fyodor Tyutchev, Aleksander Hilferding, Fyodor Buslaev, Osip Bodyansky, Viktor Grigorovich, Izmail Sreznevsky, and Vladimir Lamansky, who were prominent personalities in Russian culture and scholarship. 
Slavophilia is based on Schelling's philosophy, western European irrationalism, and Romanticism, but there was clear reference to Kollár and the messianic doctrine. Its followers considered the future as belonging to the Slavic type; they would replace the Romance and Germanic peoples, who had led mankind into decline and anarchy. The greatest contribution of this concept was that it provided a serious impetus for the development of Slavic studies as a whole and Slavic ethnology in particular.

Pan-Slavism may be the most emblematic Slavism, deeply rooted in the social awareness of western Europeans with a negative connotation. The term was used for the first time in 1826 by the Slovak amateur scholar Ján Herkel' in his treatise on the "Slavic language." Hungarian propaganda gradually started to brand any Slovak attempt at linguistic and cultural development as Pan-Slavism. Consequently, this use of the term spread beyond the boundaries of Austro-Hungary supported by the anticipated threat of establishing a consolidated Slavic nation, in which Russia would be the leading power. At the same time, a movement arose in Russia promoting the idea of a great and powerful Slavic population, organized by the Russian state to fight against foreign tyranny, also called Pan-Slavism. The main goal of this movement became to support national liberation movements (among the South Slavs in particular), even with military force. In its milder version (referred to as "cultural Pan-Slavism"), the concept was defined as an effort for understanding, rapprochement, collaboration, and mutual support among the separate Slavic nations mostly in cultural matters. As a whole, the ideology of Pan-Slavism did not have a systematic and complete version; its representatives often maintained different and even opposing views. The notion was mainly based on an idealistic concept of cultural and historical types of people: Slavs were deemed to be different and more advanced compared to Germanic and Romance peoples, and they therefore had to preserve their specific nature. Among the ideologists of Pan-Slavism, Nikolay Danilevsky and Nikolay Strakhov stand out. Many Slavophiles gravitated towards them later, as well as a range of political and military figures such as Count Nikolay Ignatyev, Prince Vladimir Cherkassky, General Mikhail Skobelev, and General Mikhail Chernyayev. Pan-Slavism had a great influence during the 1860s and 1870s, especially during the Russo-Turkish War (1877-1878). At the end of the century it gradually transformed into ultranationalism (e.g., Konstantin Leontyev) or into theocratic philosophy (e.g., Vladimir Solovyov).

The idea for political, economic, and cultural liberation and consolidation of the Slavs was resurrected at the close of the nineteenth century. The concept was quite eclectic with regard to its content because it was based on the various concepts described above: Kollárism, Austro-Slavism, Slavophilia, and Pan-Slavism. Mainly built as a political doctrine, Neoslavism promoted cohesion between Russia and Austro-Hungary, supported by France, a process that would lead to the establishment of a confederation in which the Slavs from the two empires (as well as Bulgaria and Serbia gravitating towards Russia) would be united in practice in one and the same state. 
The roads towards this goal were seen in frequent meetings between the Slavs, the establishment of information offices for common trade and industrial activities, the organization of a Slavic literary union, a union of Slavic research institutions, a Slavic telegraph agency, and so on. The most prominent ideologist of Neoslavism was the Czech politician Karel Kramár, and prominent representatives included the Czechs Jaroslav Stránský and Václav Klofáć, the Russian Vsevolod Svatkovsky, the Pole Roman Dmowski, the Croatian Stjepan Radić, and the Slovenian Leopold Lenart.

The global change in the social and political situation of the Slavs after the First World War, the establishment of the multiethnic states of Czechoslovakia and Yugoslavia (initially called the Kingdom of Serbs, Croats, and Slovenes), the restoration of the Polish state, the establishment of the Soviet Union, and other developments greatly limited the development of ideological concepts for the Slavs' consolidation, but could not completely eliminate them. On the contrary, in the 1920s the "all-Slavic" concept was raised, uniting similar ideological trends in Yugoslavia (e.g., Radovan Košutić, Todor Krajničanac, and Leonid Mashkovsky), Bulgaria (Stefan Bobchev), and Poland (Józef Musiałek) aimed at the establishment of a Slavic federation, at the foundation of a "Great Slavia." The concept of Slavic agrarianism is somewhat different: its main ideologist was the Slovak Milan Hodža. He proclaimed the thesis that because Slavic people were mainly involved in farming their consolidation could be achieved only on that basis. Unlike the other concepts for consolidating the Slavs (despite their social support and dissemination in the Slavic lands, they mainly remained ideological concepts), the followers of Slav agrarianism undertook many practical steps. Supported by agrarian parties in the Slavic countries, which were relatively strong at that time, they established the Slavic Agrarian Union and organized several all-Slavic congresses (the first of which was held in 1921). Ultimately, however, the attempts at Slavic consolidation based on agrarianism were also unsuccessful. A similar failure was experienced by the "new Slavic politics" (also referred to as the "realistic" or "republican understanding of the Slavic idea"). This was a basically harmonious concept in the 1920s and the 1930s that met no social response in the Slavic countries; it was promoted by the Czech politicians Tomáš Garrigue Masaryk and Edvard Beneš, as well as by popular Czech Slavic scholars such as Miloš Weingart, Adolf Černý, and Jan Slavík.

The attempts to develop new ideological concepts common to all the Slavs ended relatively quickly in the years after the Second World War because of the imposition of communism in Slavic countries and shifting the focus to concepts of communist internationalism.

The break between Stalin and Tito caused political and ideological efforts be limited. Consequently, efforts were reduced to and focused on scholarship and culture. It is not by chance that these decades can be characterized by the strong development of Slavic research and its institutionalization through a great number of Slavic congresses, symposia, conferences, and other scholarly forums. The last attempt (from the 1990s) 
to formulate a concept for Slavic unity of action met almost no response in the Slavic countries (despite the organization of many prominent events, including a Slavic congress in Prague) because in most of the countries the agenda by that time was aimed at integration with the rest of Europe and accession to the European Union, which practically eliminated the resurrection of the old "Slavic idea." Whether attempts of that kind will be seen again lies in the future, although at this stage the situation does not inspire partisans of Slavic unity with hope.

What is essential and quite important in this case is the fact that in practice most of the Slavic ideological concepts of the nineteenth century not only ideologically motivated the development of Slavic scholarship, but also promoted it. Usually no great emphasis is placed on this fact. On the one hand, the development of Slavic studies as a scholarly discipline is self-explained as "science about science" and the important social and community background of Slavic studies is not taken into account. On the other hand (especially recently in Czech scholarship), the emphasis is placed on the "Slavic biases" of many prominent Slavic scholars of that time, but somehow it is implicitly woven into the clichés of their Slavophilia (or Russophilia) or Pan-Slavism considered as something negative. The origin and development of ethnology in the Slavic countries is presented in a similar way. Scholars consider the establishment of Slavic studies in the context of more general European processes (a fact that is beyond doubt) and the Romantic impulses for their growth are explicitly outlined (an influence that is also unquestionable), but the role of the Slavic ideological concepts that greatly determined their origin in the discipline are left behind. However, even when this fact is taken into consideration, investigators do not examine the specific influences and stimuli of these ideological concepts, but explain things with the common denominator of general Slavic scholarly development, or they mainly look for impetus at the national level. As a matter of fact, it is no accident that in most Slavic territories scholarly interest in their own people, customs, and culture, and artistic creations was roused through a systematic manifestation of growth of self-awareness and self-knowledge as a nation, precisely in the context of their common Slavic origin.

The situation in Bulgaria is not much different. It is true that to date there is no comprehensive work devoted to the historiography of Bulgarian ethnology, but it is also true that the issue was examined by prominent figures in Bulgarian folklore and ethnography (e.g., Ivan Shishmanov, Mihakil Arnaudov, Petar Dinekov, Hristo Vakarelski (see Shishmanov (1889: 1-64), Arnaudov (1968: 70-122), Dinekov (1990: 71-163), and Vakarelski (1974: 30-106)), as well as by prominent modern researchers, especially Todor Ivanov Zhivkov and Delcho Todorov (See Zhivkov 1987: 9-54; Todorov (1989). Among them, only Todorov explicitly stated that at the very moment of its establishment ethnology was developed as a scholarly discipline under the direct and powerful influence of Slavic studies (1989: 44). He upheld the thesis that-without undervaluing the objective course and significance of Bulgarian national, social, 
economic, political, and cultural premises for the development of Bulgaria interest in ethnology - it was European Slavic studies that provided the first impulses. Todorov developed his position and stated that in the first half of the nineteenth century the main efforts of Bulgarian ethnologists were aimed at collecting folk material that would be used in foreign Slavic works (devoted to Bulgarian history and culture). These works were entirely due to the desire to clarify the nature and ethnic characteristics of the language of Cyril and Methodius (Todorov 1989: 44-47).

A similar thesis is supported today by Plamen Bochkov. In his view, the origin of Bulgarian folklore studies is related to interest in the folklore of the Bulgarian people within the boundaries of the Ottoman Empire mainly by folklore specialists from neighboring countries: the Serbian Vuk Karadžić, the Ukrainians Yuriy Venelin and Mykhailo Drahomanov, the Slovenian/Croatian Stanko Vraz, the Bosnian Stjepan Verković, and the Russians Pyotr Bezsonov and Vladimir Kachanovsky. They all collected, translated, and edited anthologies of Bulgarian folklore and thus not only attracted the attention of the European public in general, but also stimulated the interest of the Bulgarians in their own cultural heritage (Bochkov 2002: 11-12).

The process was much more complicated in practice. Two facts are beyond doubt. First, Bulgarian ethnology originated and developed in the bosom of Slavic studies, which had strengthened its position by that time. The new discipline of Slavic studies was mainly considered Slavic philology. ${ }^{2}$ Second, the founders of the new discipline were non-Bulgarian Slavic researchers. In this regard, in the context of the facts discussed above it is worth mentioning that practically all of them were more or less influenced by the Slavic ideologies dominating in their countries. In spite of his severe conflicts with Ljudevit Gaj, Vuk Karadžić put into practice one of the basic postulates of Illyrianism, codifying standard Serbo-Croatian. At the same time, Stanko Vraz was among the closest adherents of Gaj together with Ivan Mažuranić, Dimitrija Demeter, Fran Kurelac, and many others. Stjepan Verković was a prominent representative of late Illyrianism. Although Yuriy Venelin was not among the ideologists of Slavophilia, he used their support to carry out his studies in Bulgaria and after his death he was greatly honored by them. ${ }^{3}$ Among the prominent Slavophiles, Bulgarian folklore researchers such as Viktor Grigorovich and Izmail Sreznevsky stand out. Even as a student Peter Bezsonov was interested in the ideas of the Slavophiles and he turned to ethnology mostly for this reason. ${ }^{4}$ These ideas found their way to the high school in the Ukrainian town of Nizhyn, where Vladimir Kachanovsky developed as

2 See Yocov (1929; available at: http://www.libsu.uni-sofia.bg/slavica/Jocov_Slav.html.), as well as Kucarov (2002: 39-50) and Todorov (1989: 47).

3 His grave at the Monastery of the Prophet Daniel in Moscow became a pilgrimage destination for Russian Slavophiles; next to it is the grave of the Slavophilia ideologist Aleksey Khomyakov.

4 Peter Bezsonov was commissioned to publish the folklore records of Pyotr Kireyevsky, the philosopher of Slavophilia. See Peter Bezsonov, 1860-1874, Pesni, sobrannyye P. V. Kireyevskim (Songs Collected by Kireyevsky), 10 vol., Moscow. 
a Slavic scholar. ${ }^{5}$ The case of Mykhailo Drahomanov is more specific. Considered a socialist and Ukrainian separatist, he (in his own words) disseminated more Russian books in Austro-Hungary than any Slavophile from Moscow. ${ }^{6}$

All of these facts clearly show that there was a targeted strategy aimed at implementing the ideological concepts of the Slavic Revival (in spite of specific Slavisms) to achieve complete and full knowledge of the Slavic community, to develop awareness about Slavic unity in all Slavic territories, and ultimately for political and cultural consolidation within the parameters of the German national model. Another point is that this aim is completely impossible in view of the essential differences in the ethnic and historical development of the Slavs and Germans, but for the romantically disposed Slavic intellectuals of the Revival things looked different at that time.

The third point, which is a result of the two above, is related to the fact that for a very brief time the initiative of foreigners was quickly and ardently accepted by the rising Bulgarian intellectual circles. There is nothing uncommon in this trend. The Bulgarian intellectuals of the Revival era were the heirs of a crucial moment in Bulgarians' ethnic self-affirmation. The roots of this phenomenon must be sought not only in the fact that processes during the Revival involved a gradual revelation of human and humane, but also in the fact that the figures from that period were raised in an environment in which the nation, national language, culture, and national awareness were gaining strength. It is not by coincidence that these figures looked for a place to display their abilities in the three main areas of life during the National Revival: the political struggle, literature, and ethnological and folklore studies (Zhivkov 1987: 39, 15). One need only list the names of the founders of Bulgarian ethnology and folklore studies to convince readers of the correctness of this thesis: Vasil Aprilov, Georgi Rakovski, Petko Slaveykov, Dimitar and Konstantin Miladinov, Lyuben Karavelov, Kuzman Shapkarev, Nayden Gerov, and Vasil Cholakov. For several years, these Bulgarians collected, published, and studied a great number of ethnological texts (songs, fairytales, proverbs, sayings, ritual descriptions, etc.) because they considered their main purpose to be to collect as much Bulgarian folklore material as possible in order to demonstrate the identity of the Bulgarians as an ethnos with its own cultural history in line with the canons of the national revival idea. Due to their efforts, this task was not only carried

5 The Nizhyn Slavic school was established in Nizhyn (Russian Nezhin) in the second half of the nineteenth century. Its representatives included prominent Russian scholars such as Roman Brandt, Anton Budilovich, Grigoriy Ilinsky, Mikahil Speransky, and Matvey Sokolov (see Oleksandr Samoylenko, 2000, Metodolohiya istoriyi ta istoriohrafiya u naukoviy sladshchyni vchenykh Nizhyns'koyi vyshchoyi shkoly - Methodology of History and Historiography in the Scholarly Legacy of Students at the Nizhyn High School; dissertation summary, Taras Shevchenko National University of Kyiv is available at: http://www.disszakaz.com/catalog_ukr/metodologiya_istorii_i_istoriografiya_v_ nauchnom_nasledii_uchenih_nezhinskoy_visshey_shk_avtoreferat.html).

6 See Vladimir Luzganov, "Istoricheskie fakty i sobytiya, predshestvuyushchie obrazovaniyu suverennoy Ukrainy" (Historical Facts and Events Preceding the Foundation of Independent Ukraine; available at: http://www.russian.kiev.ua/bookread.php?id=63). 
out, but Europe started to overcome its tendency to look condescendingly at Bulgarian folklore, which was initially presented somewhat negatively by foreign promoters (e.g., Karadžić, Vraz, and Bezsonov). According to them, Bulgarian songs were copies of Serbian ones, and there was no Bulgarian epos because the Bulgarians had no memory of their impressive history (Bochkov 2002: 12).

The first Bulgarian folklore collections (the anthology by Rakovski, the Miladinovs, Karavelov, Shapkarev, Cholakov, and others) provided abundant and impressive folklore material that was rich and diverse and played an essential role in raising the self-knowledge and self-awareness of the Bulgarian people, and revealed its cultural achievements to the rest of the world.

It is symptomatic that one of the serious "channels" for the promotion and propaganda of Bulgarian folklore was Prague, the "Slavic Mecca." Together with Russia, the Balkan countries, and western Europe, the Czech lands were one of the cradles of education before the establishment of an independent Bulgarian state. In practice, the Czech schools and universities played a significant and indisputable role in the development of Bulgarian intellectuals during the Revival. As mentioned earlier, the orientation towards folklore studies of the Bulgarians that studied in the Czech lands is by no means accidental or arbitrary.

This is a logical result not only from personal choice, but is above all a product of the social needs and interests in Bulgaria that were typical for that time. Moreover, these activities could be considered an implementation of social assignment, a community obligation, a comprehensive and systematic guide that was inspired by the titans of the Bulgarian Revival. For Georgi Rakovsky, Dimitar and Konstantin Miladinov, and all the others, Bulgarian folk culture was a systematic part of ethnic culture. In an age when national self-awareness and self-knowledge was increasing, the interest in history increased Bulgarians' ambition to position themselves among others and to learn more about their ethnic character. ${ }^{7}$ This powerful impetus stimulated efforts not only to collect folklore, and to analyze and study it, but also to promote it and present it to the rest of the world. The facts clearly show that the Bulgarian students in the Czech lands adopted these ideas, developed them, and put them into practice. At the same time, starting from different and even opposing stances in the middle of the nineteenth century, Czech society turned its face toward Bulgaria, toward Bulgarian popular customs and culture, and toward its history and folklore (Penchev 1994, 1996). In the Czech environment, Bulgarian folklore was also politically colored; Czech political movements became one of the most important reasons for the reception of Bulgarian folklore in Bohemia (Šalanda 1990: 77-80; Robek 1989: 75-79).

7 This issue was examined in detail by Todor Ivanov Zhivkov in his unpublished article "Dimitŭr Marinov i obnovlenieto na bŭlgarskoto narodoznanie v kraya na XIX i nachaloto na XX v." (Dimitŭr Marinov and the Renewal of Bulgarian Ethnology at the End of the Nineteenth and Beginning of the Twentieth Century). 
At the same time, Slavic issues were a priority in Czech scholarship from that period. This is due to the extension of the most significant Slavic ideological concepts of that period on Czech soil, as well as to the existential needs of the developing Czech nation. In this very sense, scholarship became closely related to relevant processes and phenomena, and its parameters were defined by the actual political situation.

However, what is important in this case is that Bulgarian students in the Czech lands, the most outstanding of them being Vasil Stoyanov, Petko Stefanov, Konstantin Pavlov, Atanas Iliev, and Andrey Zehyrov (Penchev 1996: 6-36), took advantage of this area of mutual interest. The models and mechanisms were different, but all of them worked. The personal contacts were of utmost importance. On the one hand, they were prompted by a trend that was unusual but very typical for the time: close personal relations between Bulgarians and many representatives of Czech political, scholarly, and cultural intellectual circles, which involved them in the issues and aims of the national liberation movement, and in Bulgarian history and culture; very often, all of this was achieved through their acquaintance with Bulgarian folklore. One finds similar contacts among most of the Bulgarians, and the result was the involvement of the most prominent Czech intellectuals in the issues of Bulgarian ethnology and the publication of many papers in this area by František Čelakovský, Karel Jaromír Erben, Božena Němcová, Jan Gebauer, Josef Holeček, Jan Wagner, and others (Penchev 1994: 77-97, 138-159). On the other hand, there was also an institutional impact. The infiltration and participation of Bulgarian students in the activities of Czech scholarly and cultural institutions stimulated an interest in Bulgarian folklore. For instance, the Slavia Academic Society published Kytice z národnich pisni slovanských (A Bouquet of Slavic Folk Songs, 1874), in which Bulgarian works were also presented, lectures devoted to these issues were given at the Umèlecká beseda (Arts Association) cultural center, and Bulgarian folk songs were studied and sung at the Friends of the Bulgarian Language Circle. In fact, Bulgarian students used not only the opportunities provided by the cultural institutions in Prague to lecture on Bulgarian folklore, but also the clubs in the provinces, mainly in educational centers such as Tábor, Písek, and Hradec Králové (Penchev 1994: 59-77, 122-138). Furthermore, the most powerful response and the greatest practical result was achieved by the publications of young Bulgarians in the Czech press of the time. In this case it is important to point out that, among the hundreds of works on social, political, cultural, historical, geographic, and educational issues, the most significant was the share of articles dedicated to Bulgarian ethnography and folklore. It would be difficult to cite the enormous amount of publications, mostly written by Vasil Stoyanov, Vasil Atanasov, Krŭstyu Mirsky, and Andrey Zehyrov. However, it is much more important that they covered all branches of Bulgarian folklore and presented its diversity of verbal, musical, dance, and sculpted forms (Penchev 1994: 59-77, 122-138).

From everything presented so far, it is clear that in the years before independence while striving to defend Bulgarian national self-identity, the Bulgarian students in the 
Czech lands actually succeeded in present Bulgarian folk culture in a foreign ethnic environment and thus inscribed this into the broad Bulgarian ethnology movement during the Revival. It is indicative that their translations of (or help in translating) Bulgarian folklore works into Czech spread beyond the Czech borders and that they acquainted the general European public with the richness of Bulgarian folk culture. In fact, this is the very period when Bulgarian ethnology, having gained sufficient potential from the many publications of folklore works, moved to a new stage in its development: analysis, generalization, and theoretical research. Lyuben Karavelov started a new line in the development of folklore studies. By now, the main goal was not to seek the ancient origins of the Bulgarian people at any cost, as Rakovsky had done (Bochkov 2002: 13), but to reveal the systematic interconnection of cultural manifestations of the Bulgarian people. This view soon led to publications by the first serious researchers, such as Marin Drinov, Ivan Shishmanov, and Mikhail Arnaudov. At the same time, serious efforts continued to amass what is even today an impressive collection of folklore and ethnographic material, a lifetime of work by hundreds of collectors that also left their names in the annals of history. (see Dinekov 1990: 109-144) Much more importantly, Bulgarian ethnology had already started to develop in comparison to other Slavic countries and primarily sought to study its own folk culture beyond the paradigms of Slavic. Without denying the Slavic element, Bulgarian ethnologists made up for their theoretical delay (e.g., Shishmanov and Arnaudov) on the one hand, and on the other hand they tried to place the Bulgarian material in the context of pan-European cultural development. One could consider this specific feature of Bulgarian ethnology to be due to the fact that, again in contrast with most of the Slavic countries, the various Slavisms did not find widespread resonance in Bulgarian society and therefore they did not influence the paradigms of Bulgarian self-knowledge. At first glance, this position seems disputable because in Bulgaria there are followers of such ideological trends, and a Slavic congress (greatly influenced by Neo-Slavism) was even held in Sofia in 1908. However, these events could be considered as inertial, or aimed mostly at the presentation of what is "Bulgarian." As a whole, Bulgarian society (very rapidly) acquired self-confidence based on awareness of its historic place and its significance in the European past. The antiquity of the Bulgarian ethnos and the manifestations of the Bulgarian state and culture through the centuries all provided sufficient ground to develop uniquely Bulgarian ideological concepts. Figuratively speaking, in this situation Bulgarians did not need "a backup"; they were self-sufficient. In the Bulgarian environment, the Slavic consolidation trend was transformed into an inclination toward Russia; in other words, it Russified and built the ideological concept about "Grandfather Ivan" as a protector. ${ }^{8}$ Similar ideological concepts were present in the public awareness of almost all of the

8 On this topic see also Vladimir Penchev, 1993, “Oshte vednŭzh za 'Dyado Ivan”” (Once More about "Grandfather Ivan”), Bŭlgarski folklor, 19(1): 35-41. 
Slavs during the nineteenth century. They were related to the fact that Russia was the only independent Slavic country that played a significant role in European policy and culture as an empire, but in Bulgaria this focused the sense of Pan-Slavism. For this reason, Bulgarian ethnology, born in the cradle of Slavisms, later developed beyond the framework of the Slavic idea, but sought its own paths.

\section{REFERENCES}

Arnaudov, Mikhail

1968 Ocherki po balgarskiya folklor (Studies on Bulgarian Folklore). T. 1. Sofia.

Bochkov, Plamen

2002 Uvod vav folklornata kultura (Introduction to Folk Culture). Plovdiv: Plovdivsko universitetsko izdatelstvo.

Dinekov, Petar

1990 Balgarski folklor (Bulgarian folklore). Ch. 1. Sofia: Balgarski pisatel.

Kucarov, Ivan

2002 Slavyanite i slavyanskata filologiya (The Slavs and the Slavic Philology). Plovdiv: Plovdivsko universitetsko izdatelstvo.

Leontyev, Konstantin

1875 Vizantizm i slavyanstvo (Byzantine and the Slavs). Moskva.

Penchev, Vladimir

1994 Balgaro-cheshki folkloristichni kontakti prez Vazrazhdaneto (Bulgarian-Czech Folklore Contacts during the Revival.). Sofia: Universitetsko izdatelstvo „Sv. Kl. Ohridski“.

1996 Tsarstvo na zashemetyavashtata krasota. Balgarski vazrozhdentsi v Chehiya za nashiya folklor (A Kingdom of Stunning Beauty . Bulgarian Revival Intellectuals in Czech lands about our folklore). Sofia: Akademichno izdatelstvo „M. Drinov“.

Robek, Antonín

1989 Radikálni mladočeské hnutí a Bulharsko v 2. polovinè 19. století. (The Radical Youngczech Movement and Bulgaria in the second half of XIX century). - Český lid (Praha), 1989, No 2.

Shishmanov, Ivan Dimitrov

1889 Znachenieto i zadachata na nashata etnografiya (The Aims and Significance of our Ethnography.) - V: Sbornik za narodni umotvoreniya i narodopis. T. 1. Sofia.

Šalanda, Bohuslav

1990 České preklady bulharských junáckých pisni jako indikátor politického vèdomi (Czech Translations of Bulgarian Hero Songs as an Indicator of Political Awareness). - Český lid (Praha), 1990, No 2.

Todorov, Delcho

1989 Balgarskata etnografiya prez Vazrazhdaneto. (Bulgarian Ethnography during the Revival). Sofia: Izdatelstvo na BAN.

Vakarelski, Hristo

1974 Etnografiya na Balgariya (Ethnography of Bulgaria). Sofia: Nauka i izkustvo.

Wollman, Frank

1928 Slovesnost Slovanů (Slavic Oral Tradition). Praha. 
Yocov, Boris

1929 Slavyanskite literaturi $i$ slavyanskoto saznanie v Balgariya (The Slavic Literatures and the Slavic Awareness in Bulgaria). Sofia.

Zhivkov, Todor Ivanov

1987 Etnokulturno edinstvo i folklor (Ethnic and Cultural Unity and Folklore). Sofia: Nauka i izkustvo.

\section{IDEJA SLOVANSTVA IN TEMELJI RAZISKAV BOLGARSKE FOLKLORE}

V poznem 18. in v celotnem 19. stoletju je vzporedno s procesom oblikovanja slovanskih narodov in narodnih identitet potekal še proces samoidentificiranja slovanskih skupnosti. Glavni namen tega procesa je bila razmejitev Slovanov od germansko-romanskega sveta, s čimer so skusali poudariti svoj etnični substrat in poudariti, kako se manifestira skupna slovanska identiteta. V ta namen so nastali različni koncepti, ki so temeljili na filozofskih, ideoloških, kulturnih, zgodovinskih in političnih dejstvih.

Vsi ti koncepti, ne glede na precejšnje medsebojne pomenske razlike ter njihove prikrite namene in cilje, so ustvarjali obširen in vseobsegajoč sistem, ki je razkrival razvoj samozavedanja Slovanov v dolgem časovnem razponu. Pogosto so takšni koncepti vplivali drug na drugega, se prekrivali in nanašali na starejše - ali pa so postali temelji novih konceptov. Zato je najprimerneje, č jih poimenujemo s skupnim imenovalcem - slavizmom. Poljska mesianistična doktrina, kolarizem, avstro-slavizem, ilirizem, slavofilija, panslavizem, neoslavizem itd. so imeli velik družbeni vpliv in niso bili le ideološki diskurzu, temveč so odločno postavili v ospredje pomen raziskav slovanstva. Na večini slovanskih območij se je tako povecala zavest o vlogi znanstvenega zanimanju za lastne ljudi, njihove navade in kulturo ter ljudsko ustvarjalnost. Samozavedanje in samospoznavanje lastnega naroda sta bila torej pomembno povezana $z$ iskanjem skupnih slovanskih korenin.

Podoben položaj je bil tudi v Bolgariji. Bolgarska etnologija izvira iz raziskav slovanstva, novo znanstveno področje, torej slavistika, pa je bilo razumljeno predvsem kot slovanska filologija. Utemeljitelji nove vede so bili sicer nebolgarski raziskovalci slovanstva, a tudi nanje je vplivala slovanska ideologija, ki je prevladovala v tamkajšnjih deželah.

$V$ kratkem času je pobudo tujcev hitro in strastno prevzela skupina bolgarskih intelektualcev. Mnogi od njih so zbirali, objavljali in preučevali obsirna folklorna gradiva - pesmi, povedke, pregovore, reke, opise obredov itn., saj so menili, da je treba zbrati čim več folklornega gradiva, da bi tako sledili zamislim narodnega prebujenja in ideji o bolgarskem etnosu z lastno kulturno zgodovino. Zaradi njihovih prizadevanj je bilo zbranega in objavljenega izjemno veliko folklornega gradiva, kar je bilo pomembno za samozavedanje in samospoznavanje bolgarskega naroda, poleg tega pa je svetu pričalo o kulturnih dosežkih Bolgarov. Simptomatično je, da je bil eden izmed pomembnejših "kanalov"za promocijo in popularizacijo bolgarske folklore prav "slovanska meka" - Praga. V letih po osamosvojitvi so bolgarski študenti v čeških deželah dejansko uspeli zaščititi svojo nacionalno identiteto ter ohraniti bolgarsko ljudsko kulturo v tujem okolju, s čimer so se priključili širokemu pre- 
buditeljskemu gibanju, ki je bilo tesno povezano z etnologijo. O tem priča dejstvo, da so se prevodi (ali poskusi prevodov) bolgarskih folklorističnih del v češki jezik razširili tudi prej čeških meja, šimer so evropsko občinstvo seznanjali z bogastvom bolgarske ljudske kulture. Nastajajoča bolgarska etnologija je bila v primerjavi z drugimi slovanskimi deželami usmerjena skoraj povsem $k$ raziskavam lastnega folklornega izročila, in sicer tudi onkraj paradigem o konsolidiranju Slovanov. Kot kaže, so bolgarski etnologi skušali po eni strani preseči teoretski zaostanek $v$ znanosti, po drugi pa so si prizadevali postaviti ljudsko bogastvo v kontekst evropskega kulturnega razvoja. Marsikdo bi lahko pomislil, da je na tak pristop bolgarkih etnologov vplivalo dejstvo, da slavizem (za razliko od ostalih slovanskih dežel) ni bil razširjen $v$ bolgarskem javnem prostoru in zato ni tako odločilno vplival na oblikovanje paradigme o bolgarskem narodu.

Assoc. Prof. Dr. Vladimir Penchev, Institute of Ethnology and Folklore Studies with Ethnographic Museum, Bulgarian Academy of Sciences, vladimir_penchev@yahoo.com 